\title{
Crazy Blood
}

\section{Cassie Premo Steele}

\begin{abstract}
Dans ce texte, Cassie Premo Stelle, poète et chercheure universitaire, veut se réconcilier avec son passé, à travers ses souvenirs personnels ou encore l'histoire collective. Elle réfléchit sur une enfance passée dans une famille où sévissaient la maladie mentale, des problèmes liés à la nutrition, l'alcoolisme et la violence. Elle réalise du coup, comme mère et femme, que ce qui lui semblait venir d'un " mauvais sang "fait partie d'un discours narratif beaucoup plus large, historique, ce qui lui permet non seulement de comprendre mais aussi de pardonner.
\end{abstract}

I was cleaning my stepdaughter's room one day-she was nine or ten years old at the time-and I saw, on the floor, a blue and white bookmark she'd been given at school. In thick bold letters, it said, "MENTAL ILLNESS IS NOBODY'S FAULT."

I stared at it as if it was alive, afraid of it as I would have been a cockroach.

In an instant, I was eleven, ten, nine, eight, seven years old again, time whooshing past me, as I saw myself, in a plaid jumper and Mary Jane shoes, sitting patiently at a blonde wooden desk, as the teacher made her way around the room with free bookmarks.

"MENTAL ILLNESS IS NOBODY'S FAULT."

I reeled to imagine how my life might have been different if someone had told me this when I was a child.

I did not sit down and cry for what might have been. Instead, I felt angry, and I channeled this anger into cleaning, finishing her room with a fury, throwing out the bookmark along with all the candy wrappers and other trash, vacuuming with fury, and not allowing myself to look back.

Yet. 
My Irish-American father is schizophrenic.

My Irish-American mother told us this when the "papers from the pope" arrived. Because of his schizophrenia, my mother explained, my parents' divorce had been annulled by the Catholic Church because my father was mentally incompetent to make a commitment.

This would have been enough to justify the annulment, but just for good measure, my mother also told us that she had testified that she'd never wanted children.

According to the Catholic Church, if you don't intend to have children, it's not a real marriage.

An annulment means, my mother said, you were never married.

My sister and I looked at her and then my sister said, "Does that mean we're bastards?"

\section{$* * *$}

While in graduate school, I agreed to let a graduate student in psychology test me. She showed me pictures of ink blots and I told her what I saw.

I saw witches, kitties, and balloons that flew away and never came back.

A few weeks later, my therapist told me the results. She said I have "schizophrenic tendencies."

This means, she explains, that I see connections where others don't. It's as if the rest of the world splits things into different categories, like straight railroad tracks, and these tracks never cross.

I see how they might cross.

My train jumps the tracks.

I see what others don't see.

It is in my blood.

Crazy Blood.

The first time I knew my father was crazy, I was two years old.

My mother is pregnant, and we are sitting on her big bed in an upstairs apartment in Milwaukee, and she is teaching me to count. 
Out of the corner of my eye, I see my father walking down the street, away from our apartment.

"Where Daddy go?" I ask.

"He's going to the shrink," she says. "It doesn't work, but he keeps going anyway."

I am supposed to count to thirteen. I stop at twelve. I know thirteen comes next because my birthday is on a thirteen, but I pretend I don't know.

My mother gets mad.

I don't know why I pretend I don't know.

I just don't want to count anymore.

As I was sitting on that bed, refusing to count to thirteen, Ireland had the highest hospitalization rate for metal illness in the world.

Half of these patients had schizophrenia.

Half of these patients had eating disorders.

When I am four years old, the Irish will have a hospitalization rate for alcoholism twelve times higher than the British.

When I am four years old, two of every hundred males in western Ireland will be in a mental hospital.

A study published in the year of my birth will show that the Irish vulnerability to mental illness shows up in immigrant populations in the United States and Canada.

I am standing in my mother's kitchen at Thanksgiving. I am a grown woman now. My mother, never one to enjoy domestic duties, is frantically putting the last minute touches on a big meal: homemade cranberry bread, orange nut stuffing, mashed potatoes, white rolls, cranberry sauce, a green salad, and a turkey. It looks and smells delicious, and we are hungry, but she is frantic and snappish. When my sister offers her help, my mother yells, "Stay out of my way!"

"You're crazy!" my sister says to my mother.

I turn to my aunt, diagnosed as bipolar decades ago, standing quietly in a huge pink sweater, hands folded around her big belly.

"Everybody's a little crazy in this family," I say to her, quietly.

"Yes," she smiles. "I'm not the only one."

I smile back. 
"You know," she whispers, "It happens in every generation."

"What happens?" I whisper back.

"Crazy Blood. I'm the one in my generation, and before me, my mother's sister had Crazy Blood. She was in an insane asylum most of her life. She died there."

This is the first time I have heard this.

"What?" I blurt loudly. "Mom, is this true? You never told me this before!" I repeat what I have just heard to my mother.

"That's not true," she says. "That never happened. Now sit down to dinner."

I look to my stepfather. He says, "If I had a nickel for every time she said something never happened, I'd be a rich man."

Years later, now researching our family's history, trying to make the link between the history of the Irish and our Crazy Blood, I ask my aunt about this story again.

"Yes," she says. "Her name was Mary. Like your birth name. And like mine." She smiles.

We are finishing dinner in a restaurant during one of her yearly trips to visit our house-my aunt, my husband, my baby girl, and me-and I ask my husband to go take the baby for a walk outside so I can listen to her story.

"She was my mother's younger sister. Two years younger. We used to go visit her in the asylum when I was a kid. It was scary there. Scarier than anything I've ever seen."

I think about my aunt's history of bipolar disorder, how it began when she was a nun, when she was in her twenties and a third grade teacher. How the Mother Superior called my grandmother and said, "Come get her. We don't want her anymore." How she went in and out of mental institutions after that. Had shock therapy. Several times. Tried to live on her own, but couldn't. How she lived, for decades, with my grandparents. How, when they died, she moved in with my mother and stepfather. How she has had two mastectomies. And a hysterectomy. How she has a foot of pills lined up behind the bathroom sink that she must take every day.

"Scarier than you've ever seen?" I ask. "You've seen a lot."

"Yes. It was dark and dirty. Lonely. People were really crazy in there. Tied down to beds. My mother would take me to visit Aunt Mary, and each time she was fatter." 


\section{Crazy Blood · 105}

"Fatter?"

"Yes. She ate a pound of chocolates a day."

"Wow."

"Yes. And she had diabetes."

"No wonder."

"Yes. It got so bad that the doctors threatened to cut off her legs."

"From the diabetes?"

"Yes."

"But they didn't have to cut off her legs because right after they threatened to do it, she died."

"Wow."

"Yes."

Later I will ask my mother about this.

"That's not true," she will say.

"I remember going to visit Aunt Mary. She didn't die until I was fifteen years old."

According to the green book in which my grandmother recorded the history of our family - births, deaths, immigrations, citizenships - this is true.

"My mother got her moved to a nice place. It wasn't scary. It was clean. And she didn't eat chocolate. They wouldn't have allowed it. You shouldn't listen to your aunt. She's crazy."

Isn't that the point, Ma? I think.

But I say nothing.

Later, in my grandmother's green notebook, I discover that my Great Aunt Mary died on April $13^{\text {th }}$.

April $13^{\text {th }}$ is my birthday.

In the decade of my birth, the Republic of Ireland had the highest rate of psychiatric hospitalization in the world.

This was a trend that began in the last century.

In 1851, the third year of the famine, there were 2802 beds in public asylums. Ten years later there were 4623 beds. In 1871, 
there were 7831 beds.

Between 1871 and 1914, the asylum rate tripled in the West of Ireland.

So, between the time of the famine and 1914, while the population of Ireland had been reduced by one-third, the number of insane in public asylums had multiplied seven times.

$* * *$

Once when I was younger, I asked my mother why she married my father. I wanted to know what I could learn from her story, how I could avoid her mistake.

"He was from a good family," she said. They were New England bourgeoisie, owners of a hotel and a restaurant. Respected members of the community.

"He had a strong faith." His family was staunchly Catholic. My father told me once a phone call came one day to announce that he had received a full scholarship to MIT. My grandmother had asked, "Are you a Catholic school?" The caller said no. "Well," she said, "He can't go then." He-and all his brothers-went on to Notre Dame.

My father had even been in the seminary. And my mother had joined the convent. Both quit. And then they met.

"He was very smart," my mother continued. "All three of these things were important to me."

"But couldn't you see how crazy he was?" I asked.

"Yes. In fact, when I went to visit his home before we got married, I met his parents and brothers and best friend from high school. And I asked his best friend, 'Is there something wrong with him?' and he said, 'No, he's just a little different.' I should have trusted my instincts. I shouldn't have believed him."

She pauses. "But then I wouldn't have you two girls. So it was worth it. I don't regret anything."

At that moment, I knew, really knew, that my mother loved me.

Scholars debate the reasons for the high rate of mental illness among the Irish and Irish emigrants. Some blame the famine. Some blame "eight hundred years of colonization." Some blame the Irish love of wordplay and a tendency for doublespeak. Some blame the repression 
of Catholicism. Some blame child-rearing practices.

All of these reasons may be true. Or none.

$* * *$

But I can't just leave it at that. For I am a mother now.

And I fear passing on my Crazy Blood.

My daughter's eyes are blue, like mine. Blue, like my father's. I worry, sometimes, when I see her stare into space, like I do, like my father used to do, that she has inherited our vision.

Seeing what others do not see.

Is this seeing a curse or a blessing?

How much is blood and how much is history?

And what do we do with what we see?

In her book, Saints, Scholars and Schizophrenics: Mental Illness in Rural Ireland, Nancy Scheper-Hughes writes that the nature of motherchild interaction in Ireland is "schizophrenogenic."

She describes how she observed babies were kept isolated from the rest of the family, in cribs or playpens, not for hours or days or weeks or months of their life, but for years. A baby would be kept in a back room until the age of two and a half or three. If the baby cried from the back room, an older sibling was sent to put a bottle in its mouth. If it was too young to hold the bottle, the bottle would be propped. Women didn't breastfeed because they thought it would be too "draining." If the baby was particularly "cranky," it would be given brandy or phenobarbital. Later, when the baby was not a baby anymore, it was still kept penned up because the floor was too dirty for crawling. If a toddler cried, it would be slapped, told to be quiet, and then given a teaspoon of sugar to soothe it. Mothers reported that they never slapped "really young" babies. Usually they waited till the babies were at least six months old before hitting them.

****

My sister and I used to joke that my father's mother, the daughter of Irish immigrants, had dropped him on his head when he was a baby. Maybe the truth is that she never even picked him up.

Out of sight, out of mind. 


\section{Literally.}

I feel it in me, even now, this legacy.

When my toddler daughter cries hysterically, I feel myself enter the swirl of her emotion.

I want to scream, too.

I feel my hand itch to hit her.

To shut her up.

I have never done it.

But I know, from having beaten my sister when we were growing up, what it would feel like. A release. A sense of control. And then a fatigue. A kind of peace.

What comes after violence is a sense of peace.

$* * *$

What comes before violence is a kind of recognition.

A look.

In the eyes.

In her exceptional book, The Bonds of Love, psychoanalyst Jessica Benjamin explains the complex interplay between violence and recognition in the parent-child relationship.

If a child's anger causes the parent to wither, give in, and placate, the child grows up with a false sense of power. If, on the other hand, the parent refuses the child's every wish, not wanting to "spoil" her, the child's own self is what withers under the parent's harsh discipline or rage.

Between these two extremes, Benjamin argues, recognition of the other is possible - for both the parent and the child.

I believe this is possible for us as individuals-I have seen it myself, with my daughter, and with my stepdaughter before her. Yet I wonder about recognition as a collective solution, for groups who share the same violent histories.

For groups who share blood.

Where does blood end and culture begin?

Where does culture end and history begin? 
I turn toward the past.

To see.

The Irish, Scheper-Hughes goes on to say, do not believe that their children have the capacity for memory. Nor do they have the ability to bond. Nor do they feel pain before the "age of reason," at seven. So no consistency in care is necessary.

A sibling or a neighbor can bring the bottle or change the nappy. It doesn't matter.

A tired mum can slap a toddler to shut him up. It doesn't matter.

They won't remember it anyway.

What does matter, for those of us in the Catholic Irish Diaspora, is that their children are good. Instead of evil.

Children's needs are seen as "desires," and these desires can become sins.

Where does hunger stop and gluttony begin?

Where does a need for touch stop and lust begin?

Where does joy in a friend's toy end and envy begin?

So children are taught to deny their desires, to be good instead of evil.

When children cry, when they want and need and hunger, parents ignore them. They do not see them.

Eventually, the children's cries are silenced, their wants and needs and hungers are ignored. They do not see them.

And, Scheper-Hughes also points out, as their hunger is denied, Irish children begin to turn to drink to satisfy their cravings.

The bottle, full of cow's milk, thought to be the "perfect food" for babies, is in some families the only sustenance given until the age of two.

When they are hungry, the bottle is given.

When they are sad, the bottle is given. 
When they are bored, the bottle is given.

When they are in a rage, the bottle is given.

$* * *$

When my daughter cries, when rage overtakes her and she wails at the world, at me, I must see her in order not to placate her with a sweet, in order not to succumb to my frustration and hit her.

See that she is a child.

See that I was also a child.

I must see that her rage is also my rage.

That my past, my history lives on in me. And hurts still. And while responding to her with violence would, I know, soothe my pain, it would also pass on this pain to the next generation.

I see this.

My parents did not.

My grandparents did not.

My great-grandparents did not.

But I see this. Now.

My daughter's eyes are blue, like mine. Blue, like my father's. I worry, sometimes, when I see her stare into space, like I do, like my father used to do, that she has inherited our vision.

Seeing what others do not see.

Seeing how tracks can cross.

Seeing how one thing is connected to another.

How we are connected to each other.

Through blood.

Through history.

What I realize now, as a result of bearing witness to my body's memory and my family's history, is what my stepdaughter's bookmark tried to tell me years ago.

MENTAL ILLNESS IS NOBODY'S FAULT.

It is nobody's fault. There is no one to blame. Nothing to blame.

If we, as families, as cultures, as nations, as humans, are going to heal from our long and horrible histories, we have to give up the illusion of safety that comes from blaming blood. 
We must stop blaming blood and begin claiming our histories.

To see the difference between blaming blood and claiming history is to know the difference between a curse and a blessing.

And it is this blessing that I will pass on to my daughter.

It is only this that will allow us to begin again.

\section{Works cited}

Benjamin, Jessica. The Bonds of Love: Psychoanalysis, Feminism and The Problem of Domination. New York: Pantheon, 1988.

Finnane, Mark. Insanity and the Insane in Post-Famine Ireland. London: Croom Held Limited, 1981.

Scheper-Hughes, Nancy. Saints, Scholars and Schizophrenics: Mental Illness in Rural Ireland. Berkele: University of California Press, 1979. 